\title{
Sudanese Cinema: Past, Present and Future
}

\author{
Abubaker Elsiddig Ahmed Elmustafa Elsheikh Hayaty ${ }^{1}$, Chenji Yin ${ }^{1}$, Zakir Ullah', \\ Safia Yahya Hamed Ahmed ${ }^{1}$, Tian $\mathrm{He}^{2}$
}

${ }^{1}$ Department of Drama Film-TV Studies, College of Communication, Northwest Normal University, Lanzhou, China

${ }^{2}$ Sudan and South Sudan Research Center, Northwest Normal Universty, Lanzhou, China

Email: *abubakerbika123@gmail.com

How to cite this paper: Hayaty, A. E. A. E. E., Yin, C. J., Ullah, Z., Ahmed, S. Y. H., \& He, T. (2021). Sudanese Cinema: Past, Present and Future. Art and Design Review, 9, 268-283. https://doi.org/10.4236/adr.2021.93022

Received: July 26, 2021

Accepted: August 23, 2021

Published: August 26, 2021

Copyright $\odot 2021$ by author(s) and Scientific Research Publishing Inc. This work is licensed under the Creative Commons Attribution International License (CC BY 4.0).

http://creativecommons.org/licenses/by/4.0/

\begin{abstract}
Although the Sudanese Cinema started with the British colonization of Sudan, but it is still considered as undeveloped industry. The first film produced was Alarming Queen's Company of Grenadier Guards in Omdurman Battle in 1898. The history of Cinema in Sudan could be categorized into three periods according to the colonization and present cituation: colonial (1898-1956), post-independence (Mid 1950s-Mid 1980s), and recent (Mid 1980s-2010) history. Films were produced under the supervision of the General Liaison Office of the British Government till 1949; then, the Sudan Film Unit (SFU) was established to serve and highlight the progress achieved by the government and to show the development of the British Empire. Similar units were installed in different parts of Africa with other names. The 1960s-1980s witnessed the emerging of Sudanese filmmakers, directors, actors and the most famous Sudanese films. The gradual collapse of Sudanese Cinema started in the mid-1980s. The paper also highlighted the pioneer Sudanese in filmmaking, directors, actors, producers, the essential feature films directed by Sudanese directors and their awards. Governmental and private institutions related to film production since 1898 and the role played by the USA, India, European and Arab countries in Sudanese Cinema were discussed. The present Challenges facing Cinema in Sudan and the deplorable state of cinema theaters were also documented. After the 2010s active private associations, independent filmmakers, young actors and armature, who are actively engaged in filmmaking, have been trying to revive the film industry in Sudan and design its future.
\end{abstract}

\section{Keywords}

Cinema History, Culture, Film in Sudan, Cinema in Sudan

\section{Introduction}

Since independence, 1956, from the British colonization, Sudan, is suffering from 
significant mistakes in various fields, especially politics, economy and media. The positive side of the colonial rule on indigenous film was that independent local directors received comprehensive support, which enabled them to make their films (Botha, 1994). However, the country is witnessing severe backwardness in many industries and services due to internal conflict, political instability and mismanagement, leading to poverty (Ballon, 2015). Due to the absence of the scientific and practical concepts of cultural development and the tools and means of literary and artistic expression, including Cinema, Sudan also suffers from a weak relationship between the state and the aspirations of its people. War, political and religious conflicts drastically affected the filmmaking industry. It was documented that political and religious suppressions remain a significant constraint on African and Middle East Cinema and book publication (Botha, 1994; Siavoshi, 1977).

Sudan is a multicultural country; it is a mixture of African and Arab cultures, Muslims, Christians and atheists. Moreover, there are different tribes, habits, values and beliefs. Consequently, from a production point of view, the Sudanese films and cinema industry were influenced by the diversified backgrounds and Indigenous forces. Similar influential factors were reported in African countries (Diang'a, 2016). As a result, Sudanese Cinema has a limited success in improving the awareness of the reality of Sudan, which can be described as partial and modest consciousness when compared to the effect and contribution of poem, story, novel, theater, music and singing (Shaddad, 2016). In addition, the lack of competition led to the backwardness of arts and cultural creations as a whole. Consequently, very few creative works are far behind understanding the diversity and reality of Sudanese culture (Jok, 2015). Consequently, Sudanese lost Cinema as a transformation tool (Soares \& Quintella, 2008) to improve society's economy, education and culture.

Apart from a few books written in Arabic, the history of most Sudanese films produced after independence is not documented in the scientific literature, which is the case for most African countries (Botha, 1994). For this paper, intensive interviews were made with the remaining pioneer filmmakers and directors to confirm the meager information available from other sources. In this paper, the history of Sudanese Cinema is highlighted, the present situation is discussed and future guidelines are suggested.

\section{Filmmaking in the Colonial Period (1898-1956)}

After it began to spread in Europe and the United States in the nineteenth century, Cinema was introduced in Sudan. According to Bottomore (2007), several attempts were made by René Bull, Frederic Villiers and Benett-Stanford to film Omdurman Battle in Sudan in 1898. Except for Benett-Stanford, all other attempts ended up with photographs. However, Benett-Stanford was able to produce his film Alarming Queen's Company of Grenadier Guards at Omdurman in 1898 (Daly, 2004), which was distributed by Wolff Company (Table 1). Many European filmmaking companies visited Sudan to film parts of their movies 
Table 1. Some of the documentary films produced during the British colonization in 1898-1956.

\begin{tabular}{|c|c|c|c|}
\hline Year & Film & General theme & $\begin{array}{l}\text { Director, filmmaker, } \\
\text { or producer }\end{array}$ \\
\hline 1898 & $\begin{array}{l}\text { Alarming Queen's Company of } \\
\text { Grenadier Guards }\end{array}$ & $\begin{array}{l}\text { British Empire } \\
\text { development }\end{array}$ & Benett-Stanford \\
\hline 1911 & Cotton industries in Sudan & $\begin{array}{l}\text { British Empire } \\
\text { development }\end{array}$ & Great Britain \\
\hline 1912 & $\begin{array}{l}\text { Sudan: Opening the railway to El Obeid } \\
\text { Kordofan by Lord Kitchener }\end{array}$ & $\begin{array}{l}\text { British Empire } \\
\text { development }\end{array}$ & African World Film \\
\hline 1912 & Scenes in Sudan & $\begin{array}{l}\text { British Empire } \\
\text { development }\end{array}$ & Great Britain \\
\hline 1925 & Cotton growing in the Sudan & $\begin{array}{l}\text { British Empire } \\
\text { development }\end{array}$ & Brigadier A. Birtwistle \\
\hline 1925 & Life in the Sudan & Life style & KEARTON, Cherry \\
\hline 1928 & Tommy Atkins & Drama & WALKER Norman \\
\hline 1929 & Cape to Cairo & A Trip across Africa & Wardour Films \\
\hline 1929 & The Four Feathers & Fiction & COOPER Merian C. \\
\hline 1930 & Stark Nature & Nature (wildlife) & WOODS, Arthur \\
\hline 1930 & Stampede & Fiction & COURT TREATT, C. \\
\hline 1933 & Some tribes of the Southern Sudan & Life style & POWELL Cotton, P.H.G. \\
\hline 1939 & Four feathers & Fiction & KORDA, Zoltan \\
\hline 1940 & Forbidden Love & Fiction & BARONCELLI Jacques \\
\hline 1945 & Sudan & Drama & RAWLINS John \\
\hline 1946 & Negroes of the Southern Sudan & Life style & Boulton-Hawker Films \\
\hline 1947 & Sudan dispute & Politics & The Modern Age Ltd. \\
\hline 1953 & They planted a stone & Non-fiction & CARRUTHERS, Robin \\
\hline 1954 & Reconnaissance for yellow fever & Documentary & T. M. Work \\
\hline 1955 & The flaming Jungle & Culture & Great Britain \\
\hline 1956 & $\begin{array}{l}\text { United Nations security Council } 716^{\text {th }} \\
\text { meeting Feb } 1956\end{array}$ & Politics & International Agencies \\
\hline 1956 & Khartoum-West to lake Chad & Journey & Great Britain \\
\hline
\end{tabular}

(Abdul Rahim, 2015). In 1906, a French cinematographer filmed some films in Sudan for a French company.

Moreover, in 1910, Swiss director D. M. David made a film about a fishing trip in Sudan. The first film screening in Sudan took place in Elobiad (western Sudan) in 1912 as part of the celebration of the completion of the railway line (Roberts, 1987). The success of cotton production trails was shown in the film cotton industries in Sudan produced in 1911. There was a cotton-growing emphasis during the 1920s on developing the cotton industry in Kadugli, Amadi, 
Mardi and Torit and Brigadier Arthur Birtwistle produced another film, Cotton Growing in Sudan, in the late 1920s. Still, shortages of water, labor and high transport costs restricted the project's development (Daly, 2003). In the second decade of the twentieth century, the cinema "Skating Ring" in the Sudanese capital, Khartoum, began to make regular offers of silent films. Most of the audience consisted of members of the British colonial government and other foreigners. Then the British rulers introduced the roving Cinema that traveled across Sudan. This paved the way for the emergence of the first movie theater in 1930 (Abdul Rahim, 2015).

The production of documentary films was controlled by the General Liaison Office of the British Government (Table 2). In 1949 The British colonists established Sudan Film Unit (SFU) and hence the film production started in Sudan (Table 2). SFU was founded to cover the news and to produce short documentaries to serve the British colonization, using an $16-\mathrm{mm}$ camera. The Unit was associated with Sudanese filmmakers Kamal Ibrahim and Gadalla Gubara, who joined the unit. They produced all the first films of the team and wrote their scenarios. The production of this SFU was limited to documentary and cultural films (Table 1) and a bi-monthly newspaper. In 1951, the first Sudanese color film was produced. It was clear that the policies imposed by the colonizers on the SFU were to promote and enhance governmental policies and decisions, in addition to the production of short Sudanese fiction for recreation (Abdul Rahim, 2015).

Films were produced in the 1950s and early 1960s in different parts of the country, such as the South, the Nuba Mountains, the far North and the Blue Nile. Film producers were able to film many films about nature, culture, tribes and social life in many regions of Sudan. In the beginning, the Sudanese were very excited; it was the first time for them to see some parts of their country and different cultures and views from the countryside. Films produced by the Sudanese Film Production Unit were well received and admired by the spectators because they reflected Sudanese events and realities. They received them as information conveyed by a new visual medium that provides understanding and knowledge without distinction between educated and uneducated. This period was similar to that of the first film premieres of the Lumière brothers in France in the late 19th century (Mayne, 1993; North, 2001). Moreover, in this period, Arabic fiction was produced to supply roving cinema with Sudanese films and documentaries for entertainment.

The primary purpose of the foundation of the SFU was to serve and highlight the progress achieved by the country in the era of the British administration. This main objective is to put restrictions on the SFU not freely producing other types of films. However, the unit lacked qualified technical staff, resources, in addition to poor storage conditions. All these factors negatively affected the storage and preservation of the massive number of films, documentaries and issues of printed new letters produced by SFU (Abdul Rahim, 2015). The available do- 
cumentary films were classified under the following categories: places, locations, railways, media, newsreels, film magazines, social history, work, industry, aviation and feature drama. Many films were then continued to be produced in the form of documentaries, news, education and guidance. However, despite the continued production of films and the accumulation of dozens of them, Sudanese felt that these films do not reflect their real-life and culture.

Table 2. History of Governmental and private Organizations related to film production and training since the beginning of Sudanese Cinema.

\begin{tabular}{|c|c|}
\hline Organization & Nature and function of Organization \\
\hline $\begin{array}{l}1898 \text { General Liaison } \\
\text { Office } \\
\text { (Governmental) }\end{array}$ & $\begin{array}{l}\text { - The beginning of filming British battle such as Omdurman. } \\
\text { - Propaganda documentaries and news of the colonizers. }\end{array}$ \\
\hline $\begin{array}{l}1949 \text { Sudan Film Unit } \\
\text { Governmental }\end{array}$ & $\begin{array}{l}\text { - SFU was founded to cover the news and to produce short documentaries } \\
\text { to serve the British colonization. } \\
\text { - The unit owned a 16-mm film and film camera. } \\
\text { - The unit's work during that period was confined to the roving Cinema } \\
\text { and was limited to propaganda films and bi-monthly. } \\
\text { - The joint production system had been introduced to reduce pressure on } \\
\text { the cost of films and leads to the transfer of different production } \\
\text { experiences. }\end{array}$ \\
\hline $\begin{array}{l}1970 \text { State Foundation } \\
\text { for Cinema }\end{array}$ & $\begin{array}{l}\text { - One of the first co-productions was "Forests and Deserts". } \\
\text { - Three films were also produced with a French workgroup. }\end{array}$ \\
\hline Governmental & $\begin{array}{l}\text { - The foundation allowed the Sudanese to watch Oscars films and top } \\
\text { movie stars during the 1970s and 1980s. } \\
\text { - Most of the important Sudanese movies were produced during this } \\
\text { period. }\end{array}$ \\
\hline $\begin{array}{l}1972 \text { Department of } \\
\text { Film Production, }\end{array}$ & \\
\hline $\begin{array}{l}\text { Culture Department, } \\
\text { Ministry of Culture } \\
\text { and Information } \\
\text { (Governmental) }\end{array}$ & $\begin{array}{l}\text { - The Department has no real contribution due to the continuous change } \\
\text { in the affiliation to different ministries. }\end{array}$ \\
\hline $\begin{array}{l}1932 \text { First Sudanese } \\
\text { Club for Cinema } \\
\text { Private }\end{array}$ & $\begin{array}{l}\text { - A group of young Sudanese with other nationalities is interested in } \\
\text { Cinema. They wrote their view in local and British newspapers and the } \\
\text { "Sound and Light" quarterly magazine created by the British Film } \\
\text { Institute. }\end{array}$ \\
\hline $\begin{array}{l}1968 \text { Sudanese } \\
\text { Cinema Club } \\
\text { Private }\end{array}$ & $\begin{array}{l}\text { - The Sudanese Film Club presented the films of the Sudanese film } \\
\text { directors, the international and regional film festivals, as well as the } \\
\text { movie of the world's most famous directors. }\end{array}$ \\
\hline $\begin{array}{l}2015 \text { Children's Film } \\
\text { Training Initiative }\end{array}$ & - The objective was to discover and develop the skills of children in the \\
\hline Private & Children and youth ( 8 - 25 years) were trained locally and in USA. \\
\hline $\begin{array}{l}2010 \text { Sudan film } \\
\text { Factory started with }\end{array}$ & $\begin{array}{l}\text { - An independent cultural platform, produced more than } 60 \text { short films, } \\
\text { documentaries and experimental productions, many of which have taken }\end{array}$ \\
\hline Goethe-Institute & part in numerous festivals around the world in Brazil, the Netherlands, \\
\hline Private & South Korea, Japan, South Africa, Egypt, Nigeria. \\
\hline Other recent initiatives & $\begin{array}{l}\text { - Sudanese film group, Union of Sudanese Filmmakers and Cinema } \\
\text { Shabab. }\end{array}$ \\
\hline
\end{tabular}




\section{Sudanese Cinema Post-Independence (Mid 1950s-Mid 1980s)}

On 1 January 1956, Sudan got its independence from the British-Egyptian colonization. A short Independence movie (reportage film) was produced in SFU by Gadalla Gubara on this occasion. In the period 1956-1962, more than 120 short miscellaneous documentaries were produced. In 1957-58 SFU established a laboratory for the development and printing of films $(16-35 \mathrm{~mm})$ and made its film the "Day of Remembrance" in colors. The commercial investment in film production for 1960-1965 was weak, but since 1960, the government had made reasonable efforts to support educational Cinema. In seven years, the government produced about 40 short documentaries and 130 news stories to improve the public's general awareness. In addition, the roving Cinema has spread to remote places to attract viewers who do not know anything about Cinema.

The State Foundation for Cinema was founded in 1970 (Table 2) and the period 1970-1991 witnessed the golden era of the Sudanese Cinema. The first issue of the Cinema newspaper (a specialist published by the cinema Department of Culture) was issued in July 1978 and the second issue was issued in December 1978. There was a dynamic import and distribution of films from international companies such as the 20th-century fox, Metro-Goldwyn-Mayer, Paramount, United Artists Digital Studios Colombia and universal Studios. From the Arab region, the films came from companies, such as the Lebanese Company and the General Authority for Egyptian Cinema, whereas Indian movies were bought directly from film producers.

In the 1960s, names of many leading filmmakers appeared, including $\mathrm{Al}$ Khair Hashim, Mohammad Eid Zaki and Rashid Mehdi. In the 1970s and 1980s, the second generation of Sudanese filmmakers seemed skeptical of specialists, most of whom studied Cinema in Europe and Arab countries. Nevertheless, this generation showed clear progress and development in the Sudanese film scene. The most prominent directors were: Hussein Sharif, Ibrahim Shaddad, Anwar Hashim, Eltayeb Mahdi and Sami Alsawi. They worked on establishing innovative documentary films that went beyond the propaganda and documentary production of the Sudan Film Unit in its early years. They produced documentary films and short narratives, full of aesthetic art (Elmak, 2016).

Contradicting governmental directives and decisions concerning Cinema were issued in the period 1969-1974. In 1969 the governmental-issued the infamous nationalization decree, including the decision to nationalize cinema theaters. The decree of nationalization of the theaters was reversed in 1970 and the theaters were returned to their owners. These arbitrary decisions have had a negative impact on reducing the motivation for production and improvement in the reality of Cinema. In 1970 the State Foundation for Cinema was founded to accelerate film production. Moreover, in 1972 the Department of Film Production (Table 2) was founded in the Ministry of Culture and Information to support the Cinema industry. 
Furthermore, The Administrative Secretary of the Legislative Assembly presented the first legal initiative to regulate the production and presentation of films in Sudan. As a result, the Law for the Production and Control of Films was adopted in 1974 and the Cinema Law of 1949 was abolished. All these decisions, which were taken in a short period, negatively impacted Cinema in Sudan.

\section{Cinema in the Mid 1980s-2010s}

Film production in Sudan had been closely linked to the country's cultural policy and government's full support. Documentary and graduate films have found regional and international recognition due to governmental support through government departments in the Ministry. However, the State Film Foundation, the Department of Film Production and the Cinema Unit in Television Corporation were liquidated in 1991. In addition to that, the Cinema Club was closed down in the same year. Moreover, in 1993, a new film law was enacted (replacing the 1974 Act) and in 1996 another new film law was issued. These hasty unplanned decisions negatively and drastically affected cinema and film production in Sudan. Apart from a few individuals and private trials, in the 1990s-2010s, Sudan has witnessed a complete halt to cinema and film production. In that period, the official governmental bodies had shown no interest in culture in general and the film industry, which led to the neglect of Cinema. In addition to this, religious fanaticism was the primary factor that led to these retrograde decisions for the cinema industry. These decisions pointed out the ignorance of the official bodies and decision-makers about the importance of Cinema and what functions they could have done and exploited in a good way. As a result, theaters buildings deteriorated gradually with the contradicting regulations, decisions and directives and lack of optimal use. Moreover, film production started to decline since government production stopped, especially after the Department of Film Production was liquidated and the official exhibition was stopped (Elmak, 2016).

In the 1990s-2010s, most famous filmmakers, stars and actors left Sudan and migrated to different countries. They left the country to look for places that provide them with a suitable film production environment and highlight their abilities, talents and ambitions in film art. Among the famous film directors who left Sudan: Ibrahim Shaddad, Hussein Sharif and Eltayeb Mahdi. Many filmmakers believe that the deterioration of Cinema in Sudan is due to the lack of interest in the state and decision-makers. In this period, the private sector was not well prepared to close or bridge the gap immediately.

\section{Feature Films}

In the mid-1950s, it seems that the newly independent Sudanese were more interested in poetry, singing, music and foreign Cinema than the story, the novel and the theater. For them, Cinema is an essential window for recreation to see the outside world. Film producers noticed hidden interest for spectators when they watch foreign films. Kamal Ibrahim, a screenwriter and director noticed 
that Sudanese audiences were interested in discovering the reality, nature, lifestyle and behavior of other nations. He decided to present films in the form of a story that reflects some aspects of real-life and activity in the country and should also be recorded and produced in a realistic way (Abdul Rahim, 2015).

Kamal Ibrahim was very interested in producing feature films that touch the publics' feelings and hearts. This could only be achieved by choosing innovative stories through professional actors with suitable decorations alongside the rest of the elements necessary for film production. In the mid-1950s and early 1960s, Kamal Ibrahim directly directed two critical films: The Lost Childhood and The Sorrow, which can be chronicled as the first two short-lived Sudanese films (Abdul Rahim, 2015). Although many famous Sudanese writers and directors could produce different types of films, such as Tour Elgar in the clinic directed by Gadalla Gubara (Gubara, 2008), it took them almost ten years to produce features films similar to that of Kamal Ibrahim (Table 3). In 1969, Elrashid Mehdi created his film Hopes and Dreams and five years later, in 1974, Anwar Hashim made his film Shuroq. Still, the authorities did not give permission to be released and consequently, the film was not presented or shown anywhere.

The most important and influential films produced include; Tajuj directed by Gadalla Gubara was released in 1978, which tells the story of love with a tragic ending and the Journey of Eyes directed by Anwar Hashim was first presented in 1982, which tells the story of two Sudanese students who went to study in Cairo. Then Abdulrahman Mohammed directed two films, Justice above the law and Hope, which remain in the early 1990s. Finally, Gadalla Gubara produced another essential film, Blessing of Sheikh, in the late 1990s, promoting the values and beliefs and warns from the risks of ignorance. Many film producers tried to make different films, but they failed and their effort did not see the light due to technical and sometimes political reasons (Elmak, 2016).

There was no regular film production in Sudan. The lack of industrial infrastructure, necessary commercial links and financing companies were among the factors that affected the cinema industry. Moreover, there was neither proper planning nor formal colleges and schools to qualify actors and technical staff. Therefore, national films were not regularly available to be shown in cinema theaters and consequently, many foreign films were imported and presented daily across the country. This made the art of the movie outside the system of artistic culture. Sudanese Cinema, therefore, was left without support; however, creative genres and armature made their way and most of them were not successful.

For the above reasons, Sudanese filmmakers and directors failed to attract national and international investors. In the same period, in a country like Senegal, Ousmane Sembene produced his film The Driver or Carriageway, which won several prizes from various European film festivals. He drew the attention of many producers and companies that offered to finance the works that followed his first film. He thus managed to bring production and financing lights to generations of African filmmakers who appreciated the importance of craft and skills in cinematic expression (Petty, 1996). 
Table 3. Some of the famous Sudanese directed or produced films (1956-2010).

\begin{tabular}{|c|c|c|c|}
\hline Year & Name of film & Type of film & Director \\
\hline \multirow[t]{2}{*}{1952} & The Lost Childhood & Fiction & Kamal M. Ibrahim \\
\hline & The Sorrow & Fiction & Kamal M. Ibrahim \\
\hline 1955 & Song of Khartoum & Music & Gadalla Gubara \\
\hline \multirow[t]{2}{*}{1960} & Khartoum & Documentary & Gadalla Gubara \\
\hline & Tour Elgar in the clinic & Feature film & Gadalla Gubara \\
\hline 1969 & Hopes and Dreams & Feature film & Elrashid Mehdi \\
\hline 1972 & The Mausoleum & Feature film & Eltayeb Mehdi \\
\hline 1973 & The Throwing of Fire & Documentary & Hussein Shariffe \\
\hline 1973 & Shuroq & Feature film & Anwar Hashim \\
\hline 1974 & Congratulations & Feature film & Gadalla Gubara \\
\hline 1975 & The Dislocation of Amber & Feature film & Hussein Shariffe \\
\hline 1976 & Wedding of Zein & Feature film & Khalid al-Siddig \\
\hline 1977 & But the Earth is spinning & Fiction & Sulaiman Ibrahim \\
\hline 1977 & Tajuj & Feature film & Gadalla Gubara \\
\hline 1979 & Tigers Are Better Looking & Fiction & Hussein Shariffe \\
\hline 1979 & Four times for children & Education & Eltayeb Mehdi \\
\hline 1981 & The camel & Fiction & Ibrahim Shaddad \\
\hline 1982 & The Journey of Eyes & Feature film & Anwar Hashim \\
\hline 1982 & Elzar & Culture & Ali Abdal Ghayoum \\
\hline 1985 & The Robe & Fiction & Ibrahim Shaddad \\
\hline 1986 & Sons of the Sun & Documentary & Wagdi Kamil \\
\hline 1989 & The Station & Fiction & Eltayeb Mehdi \\
\hline 1996 & The story of the spoiled & Feature film & Eltayeb Mehdi \\
\hline 1998 & Sheikh's Blessing & Feature film & Gadalla Gubara \\
\hline 2000 & Circumcised & Documentary & Gadalla Gubara \\
\hline 2000 & Nuba Conversations & Documentary & Arthur Howes \\
\hline 2001 & Kafis Story & Fiction & Arthur Howes \\
\hline 2003 & The scorpion & Documentary & Wagdi Kamil \\
\hline 2005 & All About Darfur & Documentary & Taghreed Elsanhori \\
\hline 2008 & Darfur's Skeleton & Documentary & Hisham Haj Omar \\
\hline 2010 & Sittana & Documentary & Gihan Eltahir \\
\hline
\end{tabular}

Since the beginning of the seventies, many film producers have been able to produce several short films, including, but not limited to A Circle on Stone by Sami Alsawi, as well as the movie of Four times for children by Eltayeb Mahdi and The Camel by Ibrahim Shaddad and The Dislocation of Amber by Hussein Shariffe (Table 3). In the 1980s, Ibrahim Shaddad produced his film The Rope and Eltayeb Mahdi made The Station. In the 1970s and 1980s and through government funding, several short fiction films by the filmmakers Ibrahim Shaddad and Eltayeb Mahdi won several significant prizes in the region, which could have 
been completed by producing a long narrative. Nevertheless, the filmmakers were waiting for a long time for the state to play the role of the producer (Elmak, 2016; Shaddad, 2016). Films made in this period were very diverse, covering a wide range of topics and the filmmakers were trying to produce authentic and original work from their point of view (Murphy, 2000).

Some of these films were very successful from the beginning, where the director carefully selected the text, scenario, actors and crew. Thus, the resulting output was a feature film full of art, aesthetic solutions and expressive uniqueness that enabled it to compete externally and win many awards from regional and international festivals. However, many films produced were similar in many ways due to the limited experience of both actors and directors. Producers and directors were very keen from the outset to avoid the production weaknesses in the fields of scriptwriting, sound, image and dialogue; however, the lack of skilled technicians in areas of sound and lighting was one of the major problems (Shaddad, 2016). In the 1980s, the government had gone on a dubious and scandalous count of concessions until the early 1990s. The government called for the abolition of the State Film Foundation, the main producer of most feature films.

Film directors and producers in Sudan faced many political, economic and cultural challenges. One of the major problems was that arts and films are not recognized by society or by governmental authorities. The main challenges include finance and funds, governmental restrictions, civil war, cultural barriers, lack of experience, lack of qualified and skilled technical staff, absence of professional actors, untrained armature actors, shortage of proper equipment, difficulty to engage girls and women for tribal, religious or social constraints. Moreover, the reluctance of the private sector to invest in the film industry and a tax system that discourages such investment were among the main challenges facing the production of feature films in Sudan. With other difficulties faced by filmmakers, these challenges were similar to those faced by African filmmakers (Russell, 1998).

\section{Present Situation (2010-Present)}

In the 2010s, the input from some non-government agencies, individuals, amateurs, students and some private groups started to appear without governmental support or supervision. They began to take over and actively engaged in different initiatives for training programs and film production. Through their embassies in Sudan, especially from European countries, some private and foreign bodies started to perform some film activities and produce documentary films. In 2008 under the umbrella of the Goethe Institute in Khartoum, Sudan Film Factory led by the Sudanese filmmaker, Talal Afifi, was established. This had been an incentive for other private, non-governmental organizations to support the training and production documentaries. "Youth Cinema," "Chamber of the Cinema Industry," and "the Children's Film Training initiative" are among the active groups currently working in fields of training, lectures, symposia and work- 
shops to reactivate the cinema industry in Sudan. The effort of such groups produced many young talents in the area of filmmaking. In 2019, the Sudanese film Talking about trees by Sudanese director Suhaib Gasmelbari, won the Best Documentary and Audience Award for best documentary at the Berlin International Film Festival at its sixty-ninth session.

Some festivals and film awards organized by the private sector and non-governmental bodies are ongoing. The first independent film festival in Sudan was organized by the Sudan Film Factory in 2014. Film festivals such as Khartoum-Arab Film Festival, Arab Films and Directors Festival and the European Film Festival organized by the European Union mission were planned to be held annually. An "Afro-flix initiative" is a platform developed in Sudan to make it easy for film lovers to access Independent African Films. Prizes such as the "Black Elephant" and "Teharqa International Prize for Cinema and Arts" were initiated to be awarded to the best short film, best director, best actor, best screenplay, best soundtrack, best visual effects and best editing.

\section{Prizes and Awards}

Many Sudanese films and film directors won different prizes in national and international festivals. This reflects the excellent quality of these works despite the meager resource available. Among these films and directors:

- "But the Earth is spinning" directed by Sulaiman Ibrahim Golden Festival, Moscow 1979.

- 'The CameP' directed by Ibrahim Shaddad, the critics' prize at Cannes Film Festival, 1986.

- “Tajuj" directed by Gadalla Gubara, won several awards at international festivals, 1980.

- "The Rope" directed by Ibrahim Shaddad, golden prize, Damascus Festival, 1987.

- "The Mausoleum" directed by Al-Tayeb Mehdi, golden prize, Cairo Short Film Festival, 1976.

- "Nirkuk" directed by Mohammed Kordvani, the Black Elephant awarded by the Sudan Festival of Independent Cinema, Khartoum, 2017.

- "A Talk about Trees" directed by Suhaib Gasmelbari, the Best Documentary and Audience Award for best documentary film, Berlin International Film Festival, 2019.

Although the number of feature films was limited, their quality justified their different winning awards. The absence of awards in movies produced in the 1960s could be attributed to the fact that it was the beginning of Sudanese Cinema. As was expected, the prizes and awards started in the 1970s and continued in the 1980s due to the relatively rapid increase in film production. There was a gap of prizes and awards in the period 1990-2010 was due to the absence of production and there was no support from the government. The private sector contribution to film production appeared in the mid-2010s and their production qualified them to win international awards. 


\section{Governmental and Private Institutions Related to Film Production}

Table 2 shows the most important governmental, private institutions and initiatives related to film production and training since the beginning of Sudanese Cinema. The British colonizers established both the roving Cinema in 1946 and Sudan Film Unit in 1949 to serve governmental purposes. In 1971 the State Foundation for Cinema was established by the Sudanese government to promote cinema production and performances. The private Sudanese efforts to promote Cinema started in 1932 when the first Sudanese Club for Cinema was initiated. In 1968 the Sudanese Cinema Club was very active.

Different Sudanese Governments did not pay enough attention to develop Cinema. There were no clear policies for the cinema industry. The Department of Film Production (DFP) suffered many inconveniences and neglect from the continued changes in the affiliation to different ministries. This is due to changes in the emphasis and roles of each Ministry; for instance, in 1973, Cinema was affiliated to the Ministry of Information and Culture; when the television set up a film unit in 1976, the DFP became an even small department in Ministry. Moreover, in 1984 the Ministry of culture and media was established. In 2001, a new Ministry for Culture and Tourism was established as a separate ministry independent of the media. After one year, in 2002, the Ministry of Culture was utterly independent of tourism. Therefore, the Department of Film Production continued to suffer from the instability of its administrative structure.

Moreover, it did not have enough financial resources and, therefore, did not fulfill the role it assumed. Three years later, the Ministry of Culture, Youth and Sports were established following the 2005 Sudanese Peace Agreement. However, the Department remained the same without financial resources and the problem of the administrative structure remained unchanged. Five years later, the Ministry of Culture was established in 2010. However, the status of the DFP was even worse, lacking qualified technical staff and lack of foreign components of importing production inputs (photographic ore, printing, sound, chemicals and spare parts). The most important recent bodies and initiatives contributing to Cinema in Sudan include Sudan Film Factory, Children's Film Training Initiative, Sudanese film group, Union of Sudanese Filmmakers and Cinema Shabab.

\section{The Role Played by Countries in Sudanese Cinema}

Different countries such as the USA, India and some European and Arabic countries played various roles in the development of Sudanese Cinema (Table 4). Great Britain played a significant role during the colonization of Sudan 1889-1956. Through donations, training, rehabilitation equipment, or films imported from these countries. In some cases, parts of foreign films were filmed in Sudan. Joint works such as participation in Sudanese movies (actors, directors and producers) were also recorded (Table 4). However, the most influential role of these countries was the imported films. Sudanese viewers were very interested 
in foreign Movies, which they enjoyed watching while exploring different cultures and background views (Elmak, 2016).

\section{The Deplorable State of Cinema Theaters}

The second decade of the twentieth century witnessed the beginning of presenting moving pictures in Sudan in the "Skating Ring" cinema theater in Khartoum. The first public theater, which showed both sight and sound, started in Khartoum in the 1930s. After that, cinema theaters began to spread gradually in all parts of Sudan. When the Second World War ended, the number of nationwide cinema theaters reached fourteen, the number of theaters increased to reach 34 in 1959 (Banfield, 1964). In the 1980s, the number of these theaters was more than 70 across the country (Table 5). In Khartoum alone, there were more than 18 theaters. In addition, there was a minimum of three theaters in big cities such WedMadni, Elobaid and Port Sudan. According to the town, cinema theatres were built in different styles, locations and construction years. Almost all of them were open-air movie theatres auditoriums. The cinemas, set up in the 1940s and 1950s by the British, were frequented by the city's European population, Armenian, Italian, Greek and middle-class Sudanese. From the 1970s onwards, the viewers were Sudanese. In most Sudanese cities, theaters had two performances (usually 7.30 and $9.30 \mathrm{pm}$ ) every day to satisfy the demand of those interested in attending and watching different films.

Table 4. Role played by countries in Sudanese Cinema.

\begin{tabular}{|c|c|c|}
\hline $\begin{array}{l}\text { Country } \\
\text { and date }\end{array}$ & Role & $\begin{array}{l}\text { No of films } \\
\text { Imported }\end{array}$ \\
\hline & \multicolumn{2}{|l|}{ Cinema was introduced in Sudan by the British government. } \\
\hline $\begin{array}{l}\text { Great } \\
\text { Britain } \\
1898-1978\end{array}$ & $\begin{array}{l}\text { The British Film Institute retains the Colombian film collection } \\
\text { (animated images of the British Empire), including films filmed in Sudan } \\
\text { between } 1910 \text { and } 1978 \text {. The Sudanese group consists of about } 44 \text { films, } \\
\text { most of which are documentaries and a few dramas. } \\
\text { Some Sudanese had been trained in the UK. }\end{array}$ & $\begin{array}{l}\text { Films } \\
\text { imported } \\
\text { to Sudan till } \\
1971 \text { were }\end{array}$ \\
\hline Swiss land & $\begin{array}{l}\text { In 1910, the Swiss director D. M. David made a film about a fishing trip } \\
\text { in Sudan. }\end{array}$ & $\begin{array}{l}\text { 2805, of } \\
\text { which: }\end{array}$ \\
\hline $\begin{array}{l}\text { Germany } \\
\text { Early } 1970 \text { s }\end{array}$ & $\begin{array}{l}\text { The German Aid Program contributed to modernizing the equipment } \\
\text { of the Film Production Management Unit. }\end{array}$ & $\begin{array}{l}2012 \text { foreign } \\
\text { or Western }\end{array}$ \\
\hline France & $\begin{array}{l}\text { The French film Mission for Sudan, headed by Daniel Litelli visiting } \\
\text { Sudan in 1982, participated in 1-Film Bride 2-the movie Hood 3-film }\end{array}$ & $\begin{array}{l}\text { European } \\
\text { film }\end{array}$ \\
\hline 1982 & $\begin{array}{l}\text { Alzar. } \\
\text { Training programs were also delivered. }\end{array}$ & \\
\hline $\begin{array}{l}\text { America } \\
\text { The 1960s }\end{array}$ & $\begin{array}{l}\text { Rehabilitation of the buildings of Sudanese Film Unit. } \\
\text { Some Sudanese had been trained in the USA. }\end{array}$ & 242 \\
\hline India & $\begin{array}{l}\text { No obvious role. The Indian films were brought directly from the } \\
\text { production companies. }\end{array}$ & 315 \\
\hline & $\begin{array}{l}\text { Most Arabic films were brought through the Egyptian Public Authority } \\
\text { for Cinema and the Lebanese Cinema Company. }\end{array}$ & \\
\hline $\begin{array}{l}\text { Arab } \\
\text { Region }\end{array}$ & $\begin{array}{l}\text { Some Sudanese had been training in Egypt and Some Sudanese actors } \\
\text { migrated and lived in Cairo. }\end{array}$ & 478 \\
\hline & $\begin{array}{l}\text { Some Arab countries, e.g., Kuwait, participated in Sudanese films (actors, } \\
\text { directors and producers). }\end{array}$ & \\
\hline
\end{tabular}


Table 5. Some of the important cinema theaters in different parts of Sudan and their seat capacity in the early 1970s.

\begin{tabular}{|c|c|c|c|c|c|}
\hline Cinema theater & No of seats & Cinema theater & No of seats & Cinema theater & No of seats \\
\hline \multicolumn{2}{|l|}{ Khartoum } & \multicolumn{2}{|c|}{ Western Sudan } & \multicolumn{2}{|c|}{ Central Sudan } \\
\hline Friendship Hall & 1200 & Kordofan & 2000 & Almadena & 2000 \\
\hline Clozium Cinema & 3500 & Aros Elrimal & 2000 & Aljazeera & 2000 \\
\hline Khartoum West & 2500 & Dalling & 1500 & $\mathrm{Al}$ amir & 2000 \\
\hline Khartoum South & 2000 & Kadugli & 1500 & Bhri Aljazeera & 1800 \\
\hline The Nile & 3000 & Elnhood & 1200 & Elmanagel & 1800 \\
\hline Blue Nile & 1700 & Um Rawaba & 1300 & Rufaah & 1700 \\
\hline Omdrman & 3200 & El Fasher & 1800 & Sennar & 1500 \\
\hline Omdrman National & 3000 & Babnousa & 1800 & Singha & 1200 \\
\hline Pant & 1800 & Abu Jbeha & 1300 & Roussiers & 1200 \\
\hline Revolution & 2500 & Al Rahad & 1700 & Dweim & 1500 \\
\hline The bow & 2500 & Dilling & 800 & Kosti-Ahliah & 2500 \\
\hline Halfaya & 1900 & & & Kosti-victory & 2500 \\
\hline Bahri National & 2000 & & & Suki & 1800 \\
\hline Al safia & 2500 & Eastern Su & & Amid-Madani & 1100 \\
\hline Alwuhda & 2500 & National-Kassala & 2200 & May Cinema & 1700 \\
\hline Alkalakla & 1200 & Eastern-Kassala & 1500 & Civil Cinema & 1800 \\
\hline Youth Palace & 1000 & National-Gedarf & 2200 & Zamalek Medni & 1200 \\
\hline Afra Cinema & 470 & Education-Gedarf & 2000 & Elhasaheisa & \\
\hline \multicolumn{2}{|c|}{ Northern Sudan } & National-N. Hlfa & 1500 & & \\
\hline Shendi & 1800 & East New Hlfa & 1500 & & \\
\hline New Atbara & 2200 & Port Sudan & 1800 & & \\
\hline Republic-Atbara & 2500 & People-Port Sudan & 2000 & & \\
\hline National-Atbara & 3000 & Toker & 1000 & & \\
\hline Berber & 1100 & Halfa Dibrosa & 1300 & & \\
\hline Victory-Dongla & 1200 & & & & \\
\hline Elhassan-Dongola & 1200 & & & & \\
\hline
\end{tabular}

The present situation of cinemas theaters in Sudan is deplorable. This deterioration started in the mid-1990s, where Sudan's economy suffered severely, particularly when the US imposed trade sanctions over allegations that included human rights abuses. As a result, cinemas struggled to afford foreign currency releases, prompting many to buy cheap Indian films. Now, almost no theater is functioning and they became a shelter for displaced people and beggars. Some have been converted to other uses, some have been abandoned, turned into ruins and some have been completely demolished. Unfortunately, in most cities, the governmental authorities have taken cinemas theaters out of their owners in a 
cunning way and their owners have tried to keep that heritage and cultural habit, but they lost a battle against the government. As a result, most of the theaters in Sudan have been exposed to the gradual and escalating increase of obscurantism and unfair taxes that have left their owners with no other choice but to close them. A few cinema theaters such as Afraa and Friendship Hall are recently built and are still working with a limited number of customers. Most of the films offered are mainly a selection of Indian Bollywood films or American Hollywood.

\section{Conclusion}

As in most African countries, the cinematic industry was introduced into Sudan with the colonization in 1898 and started to flourish in the 1960s-1970s. Sudanese filmmakers, actors and directors produced different types of documentaries, fiction and feature films. More than 70 Film theaters were built across the country in the 1970s, where national and foreign films were presented. However, official governmental bodies, politicians and the private sector had failed in the past 30 years to improve Cinema in Sudan. As a result, filmmakers faced cultural, political, legal, financial and technical Challenges. In addition, economic hardship, heavy taxes and the civil war contributed to the diminishing of local film production. The complete absence of foreign imported films, which had a dramatic negative impact on society in general and those interested in the film industry in particular and some even left the country.

Proper management and utilization of diversity in people, culture, music, nature, habits, values and ethnic groups, as well as variety in both African and Arab cultures, give Sudan an excellent opportunity to flourish in the filmmaking industry. Furthermore, the country's diverse nature, the beauty of the Nile, flora and desert provide perfect scenes for the cinema industry that can be marketed globally. Overcoming the internal challenges, encouraging the private sector and collaborating with regional and international professional organizations are among the main factors in rebuilding cinematic production. In addition, the emerging new films, festivals and awards organized by the enthusiastic and active non-governmental agencies, associations and young amateur individuals carry a great hope to invoke Sudanese Cinema.

\section{Acknowledgements}

The authors are grateful to the Chinese Government Scholarship for sponsoring the project.

\section{Conflicts of Interest}

The authors declare no conflicts of interest regarding the publication of this paper.

\section{References}

Abdul Rahim, S. (2015). Film Pioneer Kamal Mohamed Ibrahim. Khartoum Press, 
Ballon, P., \& Duclos, J.-Y. (2015). Multidimensional Poverty in Sudan and South Sudan. OPHI Working Papers 93, University of Oxford. https://doi.org/10.2139/ssrn.2592627

Banfield, J. (1964). Film in East Africa: A Report. Transition, 13, 18-21. https://doi.org/10.2307/2934420

Botha, M. P. (1994). African Cinema: A Historical, Theoretical and Analytical Exploration. Communication, 20, 2-8. https://doi.org/10.1080/02500169408537868

Bottomore, S. (2007). Filming, Faking and Propaganda: The Origins of the War Film, 1897-1902. PhD Thesis, Utrecht University.

Daly, M. W. (2003). Empire on the Nile: The Anglo-Egyptian Sudan, 1898-1934. Cambridge University Press.

Daly, N. (2004). Literature, Technology and Modernity, 1860-2000. Cambridge University Press.

Diang'a, R. (2016). Message Films in Africa: A Look into the Past. Cogent Arts \& Humanities, 3, 1-12. https://doi.org/10.1080/23311983.2016.1146109

Elmak, N. A. (2016). The Evolution of the Documentary Film in Sudan. Sudanese Film Group.

Gubara, G. (2008). My Life with the Cinema. Sudan Press.

Jok, J. M. (2015). Sudan: Race, Religion and Violence. One World.

Mayne, J. (1993). Cinema Spectatorship. Routledge. https://doi.org/10.4324/9780203326824

Murphy, D. (2000). Africans Filming Africa: Questioning Theories of an Authentic African Cinema. Journal of African Cultural Studies, 13, 239-249. https://doi.org/10.1080/713674315

North, D. (2001). Magic and Illusion in Early Cinema. Studies in French Cinema, 1, 70-79. https://doi.org/10.1386/sfci.1.2.70

Petty, S. (1996). A Call to Action: The Films of Ousmane Sembene. Praeger.

Roberts, A. D. (1987). Africa on Film to 1940. History in Africa, 14, 189-227. https://doi.org/10.2307/3171838

Russell, S. A. (1998). Guide to African Cinema. Greenwood Press.

Shaddad, I. H. (2016). Kan Ya Makan-Beginning of Cinema in Sudan. Madarik Press.

Siavoshi, S. (1997). Cultural Policies and the Islamic Republic: Cinema and Book Publication. International Journal of Middle East Studies, 29, 509-530. https://doi.org/10.1017/S0020743800065181

Soares, J., \& Quintella, R. H. (2008). Development: An Analysis of Concepts, Measurement and Indicators. Brazilian Administration Review, 5, 104-124. https://doi.org/10.1590/S1807-76922008000200003 